\title{
El taller del historiador
}

En esta brevísima remembranza, sería imposible dar cuenta de más de medio siglo de actividades ininterrumpidas del Seminario de Historia Rural Andina, pero en cambio sí es posible afirmar, que todos los que tuvimos la oportunidad y privilegio de investigar al lado de Pablo Macera, nos beneficiamos de todo ese caudal simbólico y material que se congregaba en las instalaciones del antiguo Colegio Real de San Marcos. Como la mayoría de mi generación, cuando ingresamos a la universidad a fines de la década de los ochentas del siglo XX, muy pronto fuimos embargados por una mezcla de entusiasmo y curiosidad en torno a las actividades y publicaciones que Macera y el Seminario de Historia Rural Andina, por supuesto, desarrollaban pertinazmente, desde mucho antes que nosotros ingresásemos a la universidad.

Además de su prestigio como historiador, Macera era considerado, por lo menos, desde la década de los setenta, como uno de los intelectuales que mayor influencia ejercía sobre la sociedad y política peruana a través de sus artículos, opiniones y sobre todo entrevistas; muchas de las cuales causaron polémica. Asediado por periodistas, analistas e incluso políticos, su opinión sobre diferentes aspectos del pasado y sobre todo, del proceso político y social en curso, tenía un enorme peso de indudable efecto simbólico. A la agudeza de sus juicios, le sobrevenía una referencia histórica que coronaba una intuición como también una certeza.

Para los sectores conservadores y reaccionarios, era un francotirador porque criticaba a diestra y siniestra. Se le identificaba como intelectual de izquierda, en una época en que las agrupaciones políticas y los movimientos sociales de orientación socialista estaban en ascenso.

Imposible de olvidar algunas de sus frases célebres, por ejemplo cuando había que definir a una clase social, declaro que el Perú tenía «una burguesía de sobaco»; o para graficar el desorden, la sordidez y esas pulsiones hacia el abismo que caracterizaba a la sociedad peruana sentenció: «El Perú es un burdel». Incluso cuando la guerra civil arreciaba y la violencia política que al inicio del conflicto era una experiencia rural, y por lo tanto alejada de la costa y sobre todo, al núcleo residencial de la capital, pero que entonces ya se había trasladado a las ciudades y sobre todo a la periferia de Lima, no dudo en declarar que el futuro del país iba a ser decidido «entre las Fuerzas Armadas y Sendero Luminoso».

Incluso se llegó a señalar que Macera era el intelectual que mejor representaba a la conciencia moral del país. Justamente antes había sentenciado que, quien se «siente feliz en el Perú, es un miserable». Un personaje de tales proporciones intelectuales y que además era sanmarquino, no dejaba de enorgullecernos a quienes entonces estudiábamos historia en San Marcos; y hasta podría afirmarse que bajo su figura, el oficio de historiador adquirió un prestigio social sin precedentes.

La primera impresión que se tenía al ingresar a las instalaciones del Seminario, era una extraña sensación de trasponer a un espacio donde el tiempo estaba suspendido. Realmente los

(C) Los autores. Este artículo es publicado por ISHRA, Revista del Instituto Seminario de Historia Rural Andina de la Facultad de Ciencias Sociales de la Universidad Nacional Mayor de San Marcos. Este es un artículo de acceso abierto, distribuido bajo los términos de la licencia Creative Commons Atribución 4.0 Internacional (CC BY 4.0) [https://creativecommons.org/licenses/by/4.0/deed.es] que permite el uso, distribución y reproducción en cualquier medio, siempre que la obra original sea debidamente citada de su fuente original. 
interiores del enorme y extenso edificio que había sido concebido para educar a la elite virreinal, en la coyuntura de los ochenta del siglo pasado, donde la ciudad parecía haber enloquecido por la ira social y el terror étnico, ese antiguo claustro era una isla, un remanso que invitaba al sosiego y la meditación, no obstante la amenaza del sordo rumor que provenía de la calle, y de nuestro poco apreciado vecino: el Congreso de la República.

Los ambientes del taller del historiador, también contribuían a crear un estado de ánimo de recogimiento y que armonizaba con esas señas inconfundibles aun hasta para el historiador más bisoño, pues era la densidad del tiempo que se había asentado en los anaqueles donde se exhibían paquetes de legajos cuidadosamente anudados. Esos manuscritos que se apilaban hacia el fondo del segundo ambiente, eran una tentación para todos los que ingresaban a la trastienda del Seminario. Justamente en este ambiente se hallaba el célebre mimeógrafo del Seminario bajo la dirección y cuidado de Miguel Pinto, cuya paciencia e infinita creatividad para editar las publicaciones parecía no tener límites; cientos y cientos de títulos sobre temas y épocas disimiles, habían sido publicados de manera artesanal con el infaltable arte de Juan Zárate.

Pero además, en el Seminario uno podía conocer no solo a otros historiadores peruanos y extranjeros, estos últimos infaltables visitantes, pues también era el punto de encuentro con músicos, escritores, pintores, arqueólogos, sociólogos, pero sobre todo extraordinarios artistas populares, como Víctor Churay, Carmelón Berrocal, Enrique Cassanto a quienes tuve la suerte de conocer y tratar. Esa era otra de las facetas del Seminario, un espacio al que confluía una rica diversidad con personajes de orígenes sociales diversos, pero cuya seña común era la reflexión académica y la creatividad artística.

No menos impresionante era esa descomunal y rica biblioteca a la que se ingresaba por una sólida puerta de hierro y a la que teníamos acceso todos sus colaboradores. Sin dejar de mencionar el asombro que causaba el contemplar una impresionante variedad de objetos de arte popular formada durante décadas, provenientes de los andes, la costa y la amazonia. Su pasión por preservar diferentes registros, la sensibilidad estética de las mayorías sociales oprimidas de todas las épocas y territorios del país, lo había convertido en un consumado y perspicaz coleccionista.

Sobre la influencia de Macera en la historiografía peruana del siglo XX, como ya tempranamente lo sostuviera Cesar Puerta, en el sentido que junto a Luis E. Valcárcel, entre ambos, habrían instalado las vigas historiográficas más consistentes para la elaboración de múltiples relatos históricos de carácter nacional y cuyo eje narrativo serían las sociedades andinas. Al respecto, existe el consenso que los poco valorados -tanto por los docentes de escuela como por la academia- textos de historia crítica elaborados por Macera para las escuelas y colegios, fueron determinantes en la elaboración de dos conceptos potentes, aunque peligrosos, y que dan cuenta de tal fenómeno: la idea crítica y la noción de utopía andina.

De las múltiples anécdotas sobre su fuste como historiador nacionalista, heterodoxo, iconoclasta y director de proyectos de investigación, viene a la memoria uno con motivo del proyecto Parlamento y Sociedad, que concluyó con la publicación de varios volúmenes de fuentes documentales inéditas obtenidas del archivo histórico del Congreso de la República; y que por cierto hoy podría ayudar a explicar la conflictiva y azarosa relación entre Estado y sociedad en el Perú. Además de la paleografía, había que establecer las referencias heurísticas y redactar la sumilla pertinente, para lo cual previamente había dividido los grupos de colaboradores en función de la cronología y las áreas geográficas respectivas. 
Una extensa mesa de trabajo presidida por el propio Macera, nos servía para las coordinaciones una vez por semana y recoger sus indicaciones e intercambiar puntos de vista o sugerencias. Recuerdo que entonces recién se hacía uso de las computadoras. Una mañana, uno de nosotros, no recuerdo quien, ubico el expediente de una provincia $X$, ubicada en la fronteriza norte del país y dirigida al Congreso; su contenido causo revuelo y alguna agitación entre todos. Se trataba del acta de un cabildo abierto en donde tal provincia comunicaba su voluntad general para no pertenecer a la Republica ni al Estado peruano!, sino de formar parte del país vecino, y para cuyo efecto ya venían realizando las gestiones pertinentes. Todos fuimos convocados a la extensa mesa de trabajo y no sin cierto desconcierto Macera expresó con su habitual gravedad, algo como esto: «Yo no voy a publicar ese expediente. ¿Alguien quiere opinar?» Ahora uno puede hasta sonreír por esta anécdota, pero sin duda da cuenta sobre un aspecto de la personalidad de Macera: Su entrañable apego con el país y su destino.

En mi caso, cuando aún era estudiante y ya había iniciado las primeras exploraciones sobre la coyuntura de la independencia, fue gracias a su gestión personal que pude obtener una pequeña beca de investigación de la universidad y seguir profundizando en el tema. Pero hay que decir que por entonces, no era muy común para un alumno acceder a recursos, pues San Marcos era en esa época poco menos que un páramo académico. Presupuesto exiguo, relajo administrativo, dictadura de las dirigencias estudiantiles ideologizadas, para luego terminar con la universidad militarizada. Producto de esa primera indagación sobre las guerras por la independencia salió publicado mi primer texto sobre las guerra separatista, y desde entonces las charlas con Macera sobre este tema fueron enriqueciendo las miradas y perspectivas de análisis. (Figura 1)

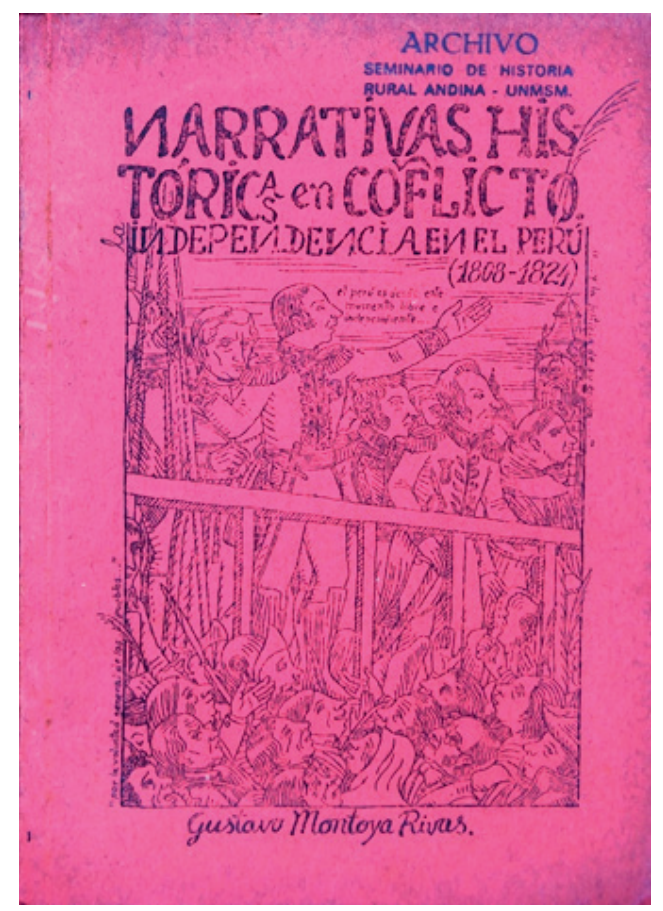

Figura 1. Carátula del libro: Narrativas históricas en conflicto. Independencia en el Perú (1808-1824). Fotografía: Omar Esquivel.

Había que ensayar todas las posibilidades hermenéuticas para ingresar a la subjetividad de los sectores plebeyos rurales, e intentar captar las estrategias de las que se valieron para trasponer la guerra. Que hayan sido ágrafos, no significa que no hayan elaborado un discurso o 
una narrativa sobre el conflicto. Hubieron de ensayar no una, sino múltiples interpretaciones, por ejemplo, sobre la presencia de los ejércitos libertadores; no fue una casualidad que las figuras de San Martín y Bolívar hayan sido asociadas con la figura del Inca. Pero ahora sabemos con mayor precisión que estos grupos sociales no estaban de ninguna manera aislados, y seguían con expectativas el desarrollo de la guerra. ¿Cómo imaginarían el desenlace y qué lecciones habrían de sintetizar cuando comprobaron que el nuevo orden republicano no era mejor que el sistema de dominio colonial?

Un tema, o para ser más preciso, una experiencia que me imponía visitar de vez en vez, a veces intempestivamente en el Seminario, era la figura del Amaru, tanto como personaje histórico, como por su aura de sacralidad que lo acompaña. Ahora podría decir que mi relación con esta divinidad andina, fue el resultado de una suma de experiencias previas, pero que tenían como hilo conductor, mi propia fascinación por Túpac Amaru II, el cacique rebelde que puso en vilo a todo el continente. Debido a que la erudición de Macera sobre este tema causaba asombro, cada vez que lo visitaba, no perdía la oportunidad de preguntar o inquirir sobre algún aspecto que podría ayudarme a despejar, una curiosidad que ya rondaba con la obsesión. Se trataba de conocer o imaginar, cómo habría sido su semblante o su imagen física. Casi sin darme cuenta, una serie de casualidades o quizás determinaciones, se fueron sucediendo hasta configurar un esquema imaginario y al que poco a poco se iban sumando piezas; como un rompecabezas o una cuadricula que debía ser completada con acontecimientos históricos y eventos contemporáneos, pero que para ser incorporados, debían calzar con lo que al inicio solo fue una sospecha. Un elemento central fue la búsqueda de razones convincentes que expliquen el potente recuerdo que se tiene sobre la figura y gesta de Túpac Amaru II. Casi por añadidura, fui visitado una y otra vez, por la suma de imágenes, lecturas e inquisiciones que siempre terminaban remitiéndome a un evento límite: el martirio, la tortura de que fueron objeto y la bárbara ejecución en la plaza de armas del Cuzco.

Como se sabe, ese día la plaza estaba a tope, las fuentes son reiterativas en señalar el silencio sepulcral durante todas las horas de la ejecución. Era claro que ahí también estaban presentes sus simpatizantes y aun quienes se habían comprometido pensando en la posibilidad del triunfo y con todo lo que en ello estaba en juego. Todas estas cuestiones las hablábamos una y otra vez cada vez que visitaba a Macera. El bárbaro descuartizamiento y la sangre derramada sobre el tabladillo que se levantó para la ejecución, hubo de ser abundante. Solo imaginar tal escenario causa consternación. Pero justo aquí es donde emerge la suma de cavilaciones, de sospechas $\mathrm{y}$ de figuraciones que tienen que ver con la existencia de formas subterráneas y sofisticadas presentes entre aquellos que se propusieron mantener un recuerdo vivo, una evocación límite, casi sagrada sobre lo acontecido. Había que levantar una epifanía. Viene a contribuir a lo que se sostendrá en seguida, el hecho que Túpac Amaru II era un ferviente católico y que además, tenía un culto íntimo y personal con el espíritu santo. ¿Cómo perennizar su martirio teniendo en cuenta la justicia de su causa y al mismo tiempo asociar su figura con la idea de la eternidad, si no era recogiendo en trozos de telas los residuos de su sangre que ahora ascendía a una santidad que habría de fortalecerse con el transcurrir del tiempo? Esta representación que fue gestándose casi de manera autónoma, bastó que se dibuje en mi memoria solo por un instante para que tal imagen quede sellada. Alguien, o muchos podrán decir que todo esto es pura imaginación. Y tienen razón. Otros dirán que tiene sentido. Y también tienen razón.

Tiempo después se me reveló la certeza de tal sospecha leyendo el pasaje de una novela de José María Arguedas, donde se recrea la entrega de un trozo de tela con la sangre del mártir como emblema y símbolo de un poder y de una legitimidad que aun subyace en la penumbra. 
No había duda que quienes en esa época, convinieron en conservar de esa forma el vestigio más excelso y potente del mártir, eran aquellos para quienes la historia como experiencia práctica y como reflexión, remitía sobre todo al futuro.

Me he animado a redactar estas pocas líneas para rendir homenaje al maestro Pablo Macera, y también para mostrar la profundidad de su pensamiento y el calado de sus reflexiones sobre diferentes aspectos, épocas, temas y figuras de la historia patria. Alguna vez el historiador británico E. Howsbann había declarado, en el sentido que en el Perú había conocido a dos grandes intelectuales cuyo compromiso con los sectores populares en el país era ejemplar: José María Arguedas y Pablo Macera.

\section{Gustavo Montoya Rivas}

gmontoyarivas@yahoo.com

Universidad Nacional Mayor de San Marcos

Publicado online: 27/12/2021 